\section{THE BOTANIC GARDEN, OXFORD*}

$\mathrm{B}^{\mathrm{Y}}$ a change of Statute, approved on March 9, the University of Oxford's ancient Botanic Garden enters yet another phase of its history.

The Garden was founded by the Earl of Danby in 1621 : it is thus the oldest Botanic Garden in Britain and the sixth oldest in Europe. In that year Danby secured the lease of a piece of swampy water-meadow from Magdalen College and made it over to the University for a physic garden. This lease has been renewed from time to time for more than three hundred years.

Danby first built the wall and gateways, then had the level of the ground raised in an attempt to avoid floods. Some time provious to $164 \mathrm{l}$ he appointed Jacob Bobart gardener on a ninety-nine-year agreement, with benefit of the produce and a payment of $£ 40$ per annum for labour and materials. Bobart on his part undertook to keep the garden planted. with trees and plants requisite for "the service and use of the said University". It would appear that Danby intended to have a "Botany Professor" also, but the Civil War broke out and funds were short. Morison, first professor, was not appointed until 1669 (obit. 1683).

The shortage of funds forced Bobart to support the Garden on what he could grow in it. There is in the archives a rather pathetic appeal (undated) to the Vice-Chancellor from Jacob Bobart jun., who succeeded his father, asking for a salary. He pointed out that the "Exoticks" he cultivated needed special care, and he thought it "a digression, to make Cairfax shine $w^{\text {th }}$ the spoils of the Physick Garden, allways haveing respect to the dignitie of the Universitie".

Bobart the younger died in 1719. The year before there had returned to England Dr. William Sherard, sometime fellow of St. John's, who had been consul at Smyrna. Sherard was a man of means with a considerable interest in botany. He regretted the state of neglect into which the Garden had fallen and entered into negotiations with the University to put botanical studies on a sounder footing. He had a remarkable library and an extensive herbarium. He proposed to found a chair of botany, with $\mathfrak{£ 3 , 0 0 0}$ endowment, nominating Dillenius, a distinguished botanist in his employ, as professor, and to leave his library and collections to the University, if the University would revive the Garden, erect the necessary greenhouses and library buildings, and make due provision for upkeep. The negotiations were protracted (Sherard mistrusted early eighteenth-century Oxford) and before they were completed he died (1728). A dispute arose between his executors and the University which dragged on for years, until it was finally settled by an award of Chancery on June 11, 1734. By it the University got the $£ 3,000$, the library and collections, and Dillenius became the first Sherardian professor. The University on its part erected the buildings, guaranteød $£ 150$ per annum for upkeep of the Garden and appointed a Perpetual Committee, consisting of the vice-chancellor, the proctors, and seven senior resident members on the "Physic Line" to see that the provisions of the award were carried out. The Royal College of Physicians was made visitor.

It is from this award in Chancery that the curators have derived their authority, and it would again become operative should the University at any time cease to maintain the Sherard collections under the custody of the Sherardian professor.

* Substance of an article in the Oxford Magazine of March 11, 1943.
It is clear from the early minute book preserved in the archives of the Department that the Perpetual Committee took its duties lightly. It met once a year (with occasional omissions) to approve the accounts and appoint a head gardener. By the beginning of the nineteenth century the Garden had again fallen into a bad state. Its revival owes much to the energy and liberality of Daubeny, Sherardian professor during 1834-67. During his tenure of office the existing range of greenhouses took shape.

In course of time the importance of the Garden as a source of materia medica became less, and its value as part of the University's equipment for the wider study of botany increased. Members of the medical faculty, as such, had less interest in the Garden, and the constitution of the Perpetual Committee was changed (1871). In 1886 an order of the Court of Chancery established a Board of six elected curators, who were given the management of the Garden under the scheme drawn up in 1734. But the same scheme had given the Sherardian professor control of the gardener, as is recognized in the statutes defining his duties! Obviously there was need for clarification.

The new Statute, just adopted, makes the professor (at present, Prof. T. G. B. Osborn), ex officio a member of the Board of Curators and confirms his duties of 'charge and supervision'. The constitution of the Board remains otherwise unaltered, and the Board as a whole is responsible for the general policy and upkeep of the Garden from the funds which it receives.

In June, 1942, Mr. W. G. Baker, who had been head gardener for more than fifty years, retired, and by good fortune the curators secured the services of Mr. G. W. Robinson, formerly superintendent of Chelsea Physic Garden, to succeed him. With his skill and experience the Garden should thrive and develop.

If by further good fortune some graduate of Oxford should be moved to give to the Oxford Garden only a part of what Cory recently bequeathed to the younger Botanic Garden at Cambridge (see NATURE of March 20, p. 328), then indeed the future of the oldest botanic garden in Great Britain would be assured.

\section{ASPECTS OF PHOTOMICROGRAPHY}

$A$ SYMPOSIUM on photomicrography was arranged by the Scientific and Technical Group of the Royal Photographic Society and took place at the Society's premises on the afternoon of February 20.

Mr. F. Martin Duncan opened the symposium with a general description of the applications of photomicrography to biological research. $\mathrm{He}$ stressed that much good work may be done by means of comparatively simple home-made apparatus. He illustrated the type of equipment he uses for low-, medium- and high-power photomicrography, and dealt with the particular requirements and dificulties of each branch in turn. For low-power work with living specimens a long-extension camera with a short-focus lens is used; it should be mounted on a rigid stand with the axis vertical. The need for rigidity increases with the magnification. For medium powers the camera is fitted to the end of a microscope tube, and for high-power work at a 